\title{
MIGRATION DECISIONS AND SITE-SPECIFIC ATTRIBUTES OF PUBLIC POLICY: MICROECONOMIC EVIDENCE FROM THE NLSY
}

\author{
Thomas A. Knapp and Nancy E. White*
}

\begin{abstract}
This paper demonstrates a relationship between migration and public policy and suggests a role for migration in regional development. Numerous studies have analyzed the relationship between migration and specific aspects of public policy, and simultaneous equations models have included public policy variables that are found to influence both firm location and migration. Yet, none of these studies has generated a comprehensive migration-oriented study of regional development that can be evaluated along with the firm location literature. Increasing evidence of the importance of public sector variables in the household location decision suggests further study of migration and regional development. Our empirical results contribute to the literature linking migration and public sector characteristics. We link migration to public policy by treating tax and expenditure variables as site attributes in a utility maximization model. We find that public sector attributes, through their effect on migration, are among the determinants of regional development.
\end{abstract}

\section{INTRODUCTION}

The purpose of this paper is twofold. The empirical results add to the increasing evidence of the importance of public policy in studies of household migration. An additional contribution of this paper is to suggest that if taxes and public expenditures influence migration, then a general theory of local or regional policy aimed at economic development must include explicit consideration of migration. The paper suggests a means by which migration theory and regional development may be integrated, motivating further research on the relationship between migration and public policies aimed at regional development.

A number of important yet disparate studies have analyzed the relationship between migration and specific aspects of public policy. However, these studies have proceeded without generating a comprehensive migration-oriented approach to economic development. For example, interstate migration has been related to public policy through studies of mobility in response to public assistance pay-

\footnotetext{
*Assistant Professor, Economics Department, Penn State University. Wilkes-Barre campus, and Assistant Professor, Economics Department, Bucknell University, respectively. The authors are grateful to Dave Ribar, Robert Gibbs, and Donald Haurin, the editors of this journal, as well as the anonymous referees for their comments on an earlier draft. Thanks also to Brian Cushing for his encouragement in the early stages of this research. Mark Gius, Claire Kreider, Ed Shihadeh, and M. Marble provided valuable assistance in constructing the data set. Any remaining errors are the responsibility of the authors.
} 
ments, unemployment benefits, and intergovernmental transfers. ${ }^{1}$ Intraurban models have analyzed the impact of public policy on the "flight" to the suburbs. ${ }^{2}$ An extensive literature consisting of simultaneous equations models finds joint causation between migration and employment growth, where public policy variables are found to influence both labor demand (employment growth) and labor supply (migration). Yet, the objective of these studies has not been to generate migration (supply side) economic development policy recommendations that may be evaluated along with that of the firm location (demand side) studies. This paper demonstrates a relationship between migration and public policy and suggests a role for migration in regional development.

Following the amenities and quality of life literature, the migration decision is cast in a utility maximization framework. Migration is posed as a consumer choice problem involving alternative locations. Public policy is linked to migration by treating public sector variables as site attributes. And, with the availability of individual migration data, we have an opportunity to overcome some of the shortcomings of aggregate net migration models. Two advantages of microdata are as follows. First, the influence of personal characteristics on migration such as age, earnings, or occupation, and public sector attributes such as taxes and public service levels, are isolated. Also, the aggregation bias associated with intermetropolitan or interstate data is reduced.

In this paper, a linkage between youth household location decisions and county-level public sector attributes is investigated using microdata from the $\mathrm{Na}$ tional Longitudinal Survey of Youth (NLSY). We have merged the NLSY with fiscal characteristics from the County and City Data Book. The youth cohort was chosen because the NLS provides a data file that reveals the geographic location in which the survey respondent resides. This data set allows us to estimate the effect of specific site attributes on the likelihood of migration. While an ideal empirical study would include the entire population, from which generalizations regarding migration behavior could be readily made, analysis of the migration behavior of youth is not trivial.

The empirical results of this paper suggest that public policy does influence household migration, and our research also clarifies the policy relevance of the supply side in regional development decisions. We do not directly establish a link of migration to specific regional development policies; instead, we suggest that migration is important to regional development and must be considered along with firm location.

We present the foundation for our theoretical model in the next section, with empirical estimates and a conclusion comprising the remainder of the paper. 


\section{AN ANALYTICAL FRAMEWORK}

Since Muth (1971), various models have characterized regional development through simultaneous equations models of the labor market. Such models use net migration or population growth as a proxy for labor supply, while employment growth represents labor demand motivated by firm location. The debate following the development of the Muth model in part focused upon the causal relationship between employment growth and net migration. From these studies, there exists evidence that "jobs follow people" (employment growth follows net migration) and that "people follow jobs" (net migration follows employment growth), and there is evidence of joint causation. Decades of study have made it clear that the connection between public policy and regional development can be explored in principle through either or both sides of the labor market.

For many years, researchers have found less than compelling evidence that regional development was enhanced by the tax and expenditure policies of state and local governments, where prevailing economic development was assumed to be driven by firm location. Firm location studies tend to examine manufacturing, which is a decreasing portion of employment growth, and focus on policy that reduces the costs or increases the benefits associated with a location. Because current regional economic growth is less oriented toward manufacturing, the policy usefulness of this approach in examining regional development is probably weakening. Although the literature regarding the influence of public policy on regional development is predisposed to models of firm location, Muth (1991) has found support for the supply-driven regional growth model, where migration is the relevant measure of changes in labor supply across regions. The impact of public policy on migration may be an increasingly important component of regional growth and merits additional analysis. We now turn to a discussion of developments in the migration and quality of life literature that establish the microfoundations of household migration behavior in response to locationspecific attributes, which may include fiscal characteristics.

Gyourko and Tracy (1989) demonstrate that local public sector characteristics are of similar importance to natural amenities in explaining quality of life among urban areas. If models of urban quality of life, which rely on migration to define preferences for site attributes, are successful in determining the importance of local public services, migration research must play a significant role in the analysis of policy aimed at regional development.

Graves and Linneman (1979) demonstrate that migration is in part the expression of changes in the demand for location-specific amenities. In the long run, spatial equilibrium exists if gains in utility cannot be experienced by relocating. If all markets are in equilibrium, any disparities in wages, rents, and local prices 
are due to compensating differences as a result of site-specific attributes. Therefore, migration is the equilibrating mechanism by which compensating differentials are realized. Whereas Graves and Linneman examine the migration decision as a response to changes in the demand for static site-specific attributes, we allow for the change in supply of these factors, since public sector attributes such as education and public welfare can change dramatically over time.

While Graves and Linneman recognized that local public sector variables could be included in the vector of site characteristics in models of household migration, their empirical work was impeded by data limitations. Therefore, the 1979 model and similar formulations such as Graves $(1976,1979,1980,1983)$ focus principally upon the influence of natural amenities on migration. These supply-side models served to establish the importance of site attributes such as climate in household location choices. However, the public policy implications are somewhat limited, since most aspects of climate are not explicitly public policy instruments.

Our migration model investigates the linkage between youth household location decisions and county fiscal structure. The empirical formulation is similar to the study of white male migration and fiscal structure done by Fox, Herzog, and Schlottmann (1989). Unlike these scholars, who use census data to estimate a logit migration model, we utilize microdata from the NLSY, merged with fiscal characteristics from the County and City Data Book. The locational choices of youth are of importance to policymakers, particularly since young people are among the most mobile segment of our population. In their study of interstate youth migration and the business cycle, Haurin and Haurin (1988) state: "From a policy perspective, state governments certainly have an interest in the interstate migration decisions of young adults. If a household moves . . . the state's tax revenues will be affected ... States also make substantial expenditures on the education and training of their youth and the return on this investment from a state's viewpoint depends on its youths' choice of future state of residence." Furthermore, Haurin and Haurin recognize that local public sector attributes such as education, hospitals, and police protection are important in residents' comparisons of perceived "quality of life" among locations. Public sector attributes, through their effect on migration, are among the determinants of regional development.

Our empirical study uses microdata to estimate the probability of migration. Aggregation bias can create difficulties in certain types of empirical models that analyze the importance of fiscal variables on migration. Macromodels, i.e., models of aggregate migration flows, are unlikely to achieve a sufficient degree of disaggregation required to provide a meaningful test of the impact of public policy attributes upon migration. Policy variables that affect migration may vary 
substantially within states or census regions, which are the typical units of measure in macro-type migration equations.

The NLSY Geocode data set utilized here provides a unique opportunity for researchers to investigate the effect of site-specific attributes upon migration using microdata. Therefore, in principle, many of the shortcomings associated with aggregate flow-based models of migration and employment growth can be avoided. In studies that use public sector variables, there are typically problems with data quality. Researchers would prefer to have data on quality of public services. As Bartik (1991) points out, "Current public spending does not control for quality of public services ... such output measures are difficult to obtain." In the next section of the paper, we establish the microfoundations of our model and discuss the empirical methodology.

\section{A MICROECONOMIC MIGRATION MODEL}

Individuals choose a location to maximize utility. When comparing alternative locations, individuals migrate to that location where utility, ceterus paribus, is greatest. In the theoretical model derived by Graves and Linneman (1979), households compare the present value of a stream of expected utilities for alternative locations based on the environmental or natural amenities associated with these sites. Suppressing the intertemporal problem of the Graves and Linneman model from our model, the indirect utility function is:

$$
\text { where: } \quad \begin{aligned}
V^{i} & =V^{i}\left(W^{i}, G^{i}\right) \\
& =\text { location } \\
W & =\text { the individual's aftertax earnings per location } \\
G & =\text { a vector of publicly provided goods consumed across sites }
\end{aligned}
$$

The probability of migration is a function of the difference in the discounted present value of utility streams available at altemative locations and is estimated using logit analysis. The general form of the equation that is estimated is

$$
\begin{array}{r}
\text { MOVE }=\mathrm{f} \text { (personal and productivity characteristics of a respondent, } \\
\text { attributes of a location, changes in attributes of the location) }
\end{array}
$$

The variable list is presented in Table 1.

The National Longitudinal Survey of Youth, which began in 1979, provides detailed information on the mobility behavior of 12,686 individuals born between 
TABLE 1

Variable Descriptions and Mean Values

\begin{tabular}{|c|c|}
\hline Variable & Mean \\
\hline MOVE $=$ respondent changed MSA in survey period & .08 \\
\hline $\begin{array}{l}\text { EDATT } 88 \text { = county educational attainment, number } \\
\text { of individuals with years of schooling } 16 \text { or greater as } \\
\text { a percentage of population } 25 \text { years and older in } 1980\end{array}$ & 16.15 \\
\hline AGE $=$ age of the respondent in 1984 survey & 23.53 \\
\hline RACE $=\mathbf{a}$ dummy variable for white or nonwhite (white $=1$ ) & .69 \\
\hline SEXD85 = a dummy variable for sex of the respondent $($ male $=1)$ & .46 \\
\hline MARD84 = marital status dummy variable $($ married $=1)$ & .28 \\
\hline $\begin{array}{l}\text { HOUSE84 = dummy variable for home ownership in } \\
1984 \text { survey }(\text { own }=1)\end{array}$ & .14 \\
\hline $\begin{array}{l}\text { KIDSD84 = dummy variable for children in household } \\
\text { or not (kids }=1 \text { ) }\end{array}$ & .32 \\
\hline $\begin{array}{l}\text { CHKIDS = dummy variable for changes in number of } \\
\text { children from } 1984 \text { to } 1985 \text { survey }\end{array}$ & .11 \\
\hline $\begin{array}{l}\text { CMAR85 = dummy variable for change in marital status } \\
\text { from } 1984 \text { to } 1985 \text { survey }\end{array}$ & .10 \\
\hline NEAST $=$ origin region for the respondent is Northeastern U.S. & .18 \\
\hline NCENT = origin region for the respondent is North Central U.S. & .24 \\
\hline WEST $=$ origin region for the respondent is Western U.S. & .20 \\
\hline $\begin{array}{l}\text { EDUC84 = education in years of the respondent from } \\
1984 \text { survey }\end{array}$ & 12.33 \\
\hline $\begin{array}{l}\text { INCOME } 84 \text { = yearly income of the respondent in survey } \\
\text { year } 1984\end{array}$ & 7081.16 \\
\hline CHINC = change in respondent income from 1984-85 survey & 1598.35 \\
\hline $\begin{array}{l}\text { NOJOBD } 84=\text { percentage of survey year } 1984 \text { that the } \\
\text { respondent was unemployed }\end{array}$ & .10 \\
\hline $\begin{array}{l}\text { NOJOBD } 85=\text { percentage of survey year } 1985 \text { that the } \\
\text { respondent was unemployed }\end{array}$ & .08 \\
\hline $\begin{array}{l}\text { CHUNEMP = difference in county's unemployment rates } \\
\text { from } 1984-85 \text { surveys }\end{array}$ & -.06 \\
\hline $\begin{array}{l}\text { EDUCEXP }=\text { county's educational expenditures in } 1982 \\
\text { as a percentage of total county expenditures in } 1982\end{array}$ & .65 \\
\hline $\begin{array}{l}\text { PUBEXP = county's public welfare expenditures in } 1982 \\
\text { as a percentage of total county expenditures in } 1982\end{array}$ & .07 \\
\hline
\end{tabular}


TABLE 1 (continued)

\begin{tabular}{|c|c|}
\hline Variable & Mean \\
\hline $\begin{array}{l}\text { HIWAYEXP = county's highway expenditures in } 1982 \\
\text { as a percentage of total county expenditures in } 1982\end{array}$ & .08 \\
\hline $\begin{array}{l}\text { POLICEXP }=\text { county's police expenditures in } 1982 \\
\text { as a percentage of total county expenditures in } 1982\end{array}$ & .08 \\
\hline $\begin{array}{l}\text { HOSPEXP = county's health and hospital expenditures } \\
\text { in } 1982 \text { as a percentage of total county expenditures in } 1982\end{array}$ & .13 \\
\hline $\begin{array}{l}\text { TAX8 = county's total tax revenues in } 1982 \text { as a } \\
\text { percentage of county income }\end{array}$ & 86.23 \\
\hline $\begin{array}{l}\text { FGENEXP = intergovernmental transfers in } 1982 \text { as } \\
\text { a percentage of total county expenditures in } 1982\end{array}$ & .68 \\
\hline $\begin{array}{l}\text { CHED = change in expenditures on education (1977-1982) } \\
\text { as a percentage of the total direct general } \\
\text { expenditures of the county in } 1977\end{array}$ & .88 \\
\hline $\begin{array}{l}\text { CHPUBWEL }=\text { change in expenditures on public } \\
\text { welfare }(1977-1982) \text { as a percentage of the } \\
\text { total direct general expenditures of the county }\end{array}$ & .11 \\
\hline $\begin{array}{l}\text { CHPOLICE = change in expenditures on police } \\
\text { protection (1977-1982) as a percentage of the } \\
\text { total direct general expenditures of the county in } 1977\end{array}$ & .14 \\
\hline $\begin{array}{l}\text { CHHHOSP }=\text { change in expenditures on health and } \\
\text { hospitals }(1977-1982) \text { as a percentage of the } \\
\text { total direct general expenditures of the county in } 1977\end{array}$ & .19 \\
\hline $\begin{array}{l}\text { CHHIWAY = change in expenditures on highways } \\
\text { (1977-1982) as a percentage of the total direct } \\
\text { general expenditures of the county in } 1977\end{array}$ & .10 \\
\hline $\begin{array}{l}\text { CHFGEN = change in intergovernmental transfers } \\
(1977-1982) \text { as a percentage of total direct } \\
\text { general expenditures of the county in } 1977\end{array}$ & 1.01 \\
\hline $\begin{array}{l}\text { CTAX }=\text { origin county's change in tax revenues } \\
(1977-1982) \text { as a percentage of county personal income }\end{array}$ & 55.18 \\
\hline $\begin{array}{l}\text { CRIME = change in numbers of serious crimes } \\
\text { per } 100,000 \text { from } 1980-85\end{array}$ & -52.24 \\
\hline $\begin{array}{l}\text { CITYD = dummy variable for center city residence. } \\
(1=\text { not center city })\end{array}$ & .32 \\
\hline CCRIME $=$ interacts the variable CRIME with CITYD & -140.81 \\
\hline $\begin{array}{l}\text { WHITE = occupation dummy variable. Refers to } \\
\text { managerial, professional, and technical workers }\end{array}$ & .13 \\
\hline $\begin{array}{l}\text { SERVICE = occupation dummy variable. Refers to employees } \\
\text { categorized as sales, administrative support, clerical, and service }\end{array}$ & .43 \\
\hline
\end{tabular}


1955 and 1965. A Geocode data file matches individuals to a specific county, which permits reseachers to merge individual personal and productivity characteristics with the attributes of the county in which the person resides at any point in time. The data set provides a unique opportunity to study the influence of specific locational attributes upon migration behavior using microdata. Our choices of personal characteristics and their changes follow the work of Graves and Linneman (1979) and Linneman and Graves (1983).

We estimate the migration behavior of youth aged 19-29 during the survey period 1984-85. We chose this time period for several reasons. First, the time period is not unusual in terms of national business cycle, which is exogenous to the locality, but may affect the propensity to relocate. Second, by 1984-85, many of the respondents were old enough to have joined the labor force. Third, we were able to merge similar mobility time intervals with the fiscal variables from the County and City Data Books of 1983 and 1988.

After we omitted students and military personnel, the sample consisted of 7,954 individuals, with 588 youth who had moved during the survey period. The respondents remaining in our sample are disproportionately nonwhite, female, low income, and noncenter city residents of the southern United States. The mean age is 23.53 years, with an average education level of 12.33 years. Thirty-two percent of the sample have children. Married persons constitute 28 percent of the respondents.

Migration is defined in terms of a change in MSA over the time interval 1984-85. Variables that capture personal and productivity characteristics are income, gender, race, age, duration of unemployment, marital status, family size, home ownership, occupation, and educational attainment, along with changes in the following variables: number of children, marital status, and income. Past migration history, commonly used as an explanatory variable in migration models of mature migrants, is omitted in this study. Given the age distribution of this sample, it is unlikely that young migrants have prior migration histories as meaningful as adult movers.

A dummy variable for region is constructed, which may capture differences in whether individuals of different regions respond differently to location-specific attributes not captured by the other measures subsequently described. As suggested by Carlino and Mills (1987), a regional dummy variable might also proxy natural amenities such as climate.

In addition to these variables, characteristics of the local labor market are included. These attributes include the origin county's unemployment rate in 1984, county educational attainment, and changes in the county unemployment rate. The origin county's fiscal characteristics are matched to the respondent's county of 
origin, providing a means by which fiscal attributes and cumulative changes in fiscal characteristics may affect the location choice.

The fiscal variables are merged with the Geocode data and are from the County and City Data Book $(1983,1988)$. At the county level, data on fiscal variables are limited to observations for 1977 and 1982. Of interest are both levels and intertemporal changes in the levels of all personal characteristics, as suggested by Graves and Linneman (1979), Linneman and Graves (1983), and Krumm and Kelly (1988). We also attempt to determine the importance of fiscal levels in 1982 and intertemporal changes from 1977 to 1982 in fiscal conditions on migration decisions, perhaps a more appropriate method of measuring fiscal attributes on location choices.

As in Fox, Herzog, and Schlottmann (1989), tax liabilities associated with a county are expressed as a percentage of county income. Counties presumably differ in the tax revenues generated per dollar of county income, a proxy for the cost of acquiring publicly provided goods attributed to a particular county. Changes in tax revenues generated are expressed also as a percentage of county income. Other public sector variables include 1982 intergovernmental transfers and levels of county spending as a percentage of total expenditures in 1982. Spending includes the following categories: education, health and hospitals, police, highways, and public welfare. Changes in all expenditure categories and transfers as a percentage of beginning year spending are included.

Crime is identified as 1984 levels and changes (1984-85) in serious crimes per 100,000 . Also included is a term that interacts changes in serious crimes and center city residence. The purpose of this variable is to determine if changes in crime affect the mobility of center city residents differently from noncenter city residents.

\section{EMPIRICAL RESULTS}

The empirical results are presented in Table 2. Model 1-the model without site characteristics-is compared to Model 2, which includes the vectors of locational attributes and changes in those attributes. The log-likelihood ratio test statistic indicates that each model is significant at the 1 percent level. The null hypothesis that the coefficients of the fiscal and nonfiscal characteristics of a location are jointly zero is rejected at the 1 percent level. Therefore, fiscal characteristics are significant in explaining migration behavior. 
TABLE 2

Logit Estimates: 1984-85 MSA Migration Determinants of Youth for Personal, Productivity, and Area Characteristics, including the Public Sector

\begin{tabular}{lcc}
\hline \hline Variable & Model 1 & Model 2 \\
\hline Constant & $-4.12879 * * *$ & -128.504
\end{tabular}

Personal and Productivity Characteristics

$\begin{array}{lll}\text { Age } & -.022089 & .009755 \\ \text { Race } & .435628 * * * & .460293 * * * \\ \text { Sex } & .336757 * * * & .308054 * * * \\ \text { Marital status } & .186495 & .104456 \\ \text { Own house } & -.878216 * * * & -.846864 * * * \\ \text { Children in home } & -.180185 & -.206417 \\ \text { Educational attainment } & .133163 * * * & .119401 * * * \\ \text { Jobless in 1984 } & .012097 & .0428535 \\ \text { Jobless in 1985 } & .740565 * * * & .805311 * * * \\ \text { Income 1984 } & -.000032 * * * & -.000028 * * * \\ \text { Change in number of children } & .125753 & .174008 \\ \text { Change in marital status } & .692808 * * * & .633406 * * * \\ \text { Change in income } & .000001 & .000000 \\ \text { Employed in service sector } & .147130 & .167148 \\ \text { Employed in profession } & .173988 & .103277\end{array}$

Area Nonfiscal Attributes

Region of residence

Northeast

$-.119623$

North Central

West

$-.460938 * * *$

.042188

Educational attainment of county

$.029456 * * *$

Unemployment rate in 1984

.000804

Change in unemployment rates

$.005863 *$

Crime

.000053

Change in crime

$.000098 * *$

Change in crime interacted with central city

$-.000215 * * *$

Change in percentage of whites

Public Sector Characteristics

Educational expenditures

123.745

Public welfare expenditures

121.508

Police expenditures

119.529

Hospital expenditures

122.136

Highway expenditures

126.263

Change in educational expenditures

$-.502623 * * *$

Change in public welfare expenditures

$-.187329$ 
TABLE 2 (continued)

\begin{tabular}{|c|c|c|}
\hline Variable & Model 1 & Modal 2 \\
\hline Change in police expenditures & & -1.03775 \\
\hline Change in hospital expenditures & & $.379736 *$ \\
\hline Change in highway expenditures & & -1.16069 \\
\hline Local govemment taxes & & .001065 \\
\hline Change in taxes & & $.005740 *$ \\
\hline Intergovernmental transfers & & $-1.29750 * * *$ \\
\hline Change in intergovernmental transfers & & $1.09787 * * *$ \\
\hline
\end{tabular}

\footnotetext{
* $\mathrm{t}$ - test significant at .10 level

** $\mathrm{t}$ - test significant at .05 level

*** t- test significant at .01 level
}

The log-likelihood ratio test statistic is significant at the .01 level in each model. The value of the log-likelihood function for the restricted model is -2097.3. The value of the log-likelihood function for Model 1 is -2013.8. The value of the log-likelihood function for Model 2 is -1558.1 .

At the .15 level, the following variables are significant: police, hospital, highway, education, public welfare expenditures, and change in highway expenditures.

\section{Personal and Productivity Variables}

The results obtained for the personal characteristics are generally consistent with those of the migration literature, with exceptions that relate to the nature of the sample. Race, gender, educational attainment, and income are significant determinants of mobility with the anticipated signs. Current period experience of unemployment has a statistically significant and positive impact on the likelihood of migration, while the coefficient on unemployment duration from the prior survey year is not statistically significant at the 10 percent level. The latter result stands in contrast to the typical result in studies of nonyouth populations. Change in marital status exerts a positive influence upon migration as anticipated. Home ownership has the expected effect of reducing the likelihood of migration.

Age, marital status, presence of or changes in the number of children, and occupational dummies are not significant. However, given that the sample is of young adults, these results are consistent with expectations. Within this narrow age cohort, variations in these specific characteristics are relatively unimportant compared to other factors. For example, while the youth cohort is one of the most highly mobile in the population, changes in age within this cohort exert little influence upon migration behavior. 


\section{Area Nonfiscal Attributes}

County educational attainment is positively associated with the likelihood of migration and likely reflects labor market competition in a given county. Increases in county unemployment rates raise the likelihood of migration, indicating that weak local employment prospects increase the likelihood of migration. Incidence of crime per 100,000 residents is not a statistically significant determinant of migration, although changes in crime per 100,000 have the effect of reducing the likelihood of migration. However, CCRIME, which interacts changes in crime with noncenter city residence, has a negative coefficient and is significant at the 1 percent level. These two results seem plausible, given the different choices available to center city residents versus noncenter city residents. Confronted with an increase in crime rates, the center city resident faces the possible choice of flight to the suburbs to escape crime. The suburban resident facing a similar increase in the crime rate is not likely to view relocation to another suburb as a plausible means of reducing exposure to crime.

The only statistically significant regional dummy variable is for the North Central region, with a negative sign. This variable may reflect the lagging economy of the region in the period, relative to other regions of the United States.

\section{Public Sector Variables}

At the .15 level or less, all of the expenditure variables are significant, and only changes in public welfare and changes in police expenditures are insignificant. Local government tax revenues, as a percentage of county income, are insignificant, while changes in this variable are significant at the 10 percent level. The variables that measure intergovernmental transfers as a percentage of total expenditures and changes in intergovernmental transfers are both significant at the 1 percent level.

After an examination of the correlation coefficients, it is evident that the public sector variables, particularly the expenditure categories, are highly collinear. Multicollinearity reduces the precision of the estimates by inflating the standard errors for regression coefficients. In these models, the (in)significance of certain coefficients is critical for the interpretation of the results. If researchers attempt to reduce the impact of multicollinearity by dropping certain offensive variables, then omitted variables bias becomes a particularly important consideration. Alternative specifications of the fiscal characteristics were estimated, but the results suggested that multicollinearity is not a problem. ${ }^{3}$ Given that the t-statistics are downwardly biased in the presence of multicollinearity, the level of significance of these variables leads to optimism with respect to the importance of 
fiscal factors in youth migration decisions, yet leaves an empirical problem that we will not solve in this paper.

While we hypothesized that the current levels and composition of expenditures, as captured by our expenditure variables, and the changes in these variables influence mobility, it appears that the cumulative changes are better predictors of youth migration behavior. In this regard, the change in educational expenditures variable is significant at 1 percent while changes in both hospital expenditures and taxes are significant at the 10 percent level.

Perhaps these results are best understood by considering the personal characteristics of the sample. Recall that the typical respondent is young, not a homeowner, with nearly one-third having children. Although our data set did not allow us to disaggregate own-source revenues, it is well known that property tax is the single most important source of internally generated revenues at this level of government. Given that there are few respondents who are homeowners and would be responsive to property tax levels, perhaps this result is not unusual. Also, for those youth who own homes, it may be that levels of taxes as a percentage of county income are not necessarily deterrents to a location, if those taxes contribute to a menu of desirable public services.

Although levels of expenditures could be important to the perceived "quality of life" of a location, these empirical results demonstrate that the responsiveness to changes in levels of expenditures is relatively more important in the migration decision. The change in educational expenditures is of the expected sign and is significant. Of the respondents with children, these children are likely to be of pre-school or elementary school age. Since educational expenditures on children of this age are provided at the local level, these individuals are very likely to be sensitive to changes in educational expenditures.

An initial appraisal of the changes in the health and hospital expenditures variable may lead one to conclude that this variable is of the wrong sign. Again, consider that this is an analysis of youth migration. The young people of this sample, typically unmarried and childless, would be less likely to be responsive to expenditures on health and hospitals.

The intergovernmental transfer variable is of the anticipated sign and is significant at the 1 percent level. We would expect that the greater the contribution of federal and state governments to the provision of local public services, the more desirable an area becomes, which likely reduces the probability of moving. However, the sign of changes in transfers as a percentage of total expenditures is unexpected. 


\section{v. CONCLUSION}

The empirical results of this paper contribute to the increasing evidence that individuals are responsive to the tax and expenditure policies of lower-level governments. We demonstrate that local fiscal characteristics are significant explanatory determinants in the migration decisions for the youth cohort of the NLS in 1984-85. While results based on youth data cannot be generalized to the population, evidence that fiscal attributes are important in location choice for any subgroup of the population is significant. If individuals are responsive to public policy attributes of a location, then a role for migration exists along with firm location in studies of regional development. We attempt to integrate migration theory and regional development, since such considerations are not yet an integral component of migration theory, nor is migration theory perceived as an essential instrument of regional development. Future research must formulate an explicit link between migration and regional development. The methodology we have used in this paper has its foundations in utility maximization models and microdata and suggests that the supply side is important to regional development. Policy recommendations formulated from supply-side studies are not yet directly comparable to those of firm location.

\section{ENDNOTES}

1. Shaw (1986) studied the impact of fiscal policies such as unemployment benefit payments and intergovernmental grants to provinces upon migration flows for Canada. Widner and Cornia (1978) found that personal income tax policies may have more impact on economic development than the tax incentives currently aimed at firm location. Wasylenko and McGuire (1985) found that individuals may (re)locate to that area where state personal income taxes are low, seeking real income gains. In Carlino and Mills's (1987) study of the determinants of county growth, it is concluded that "one policy prescription for local economic development officials is to formulate strategies to retain or attract population and employment will follow ... public funds may be better spent on educating the resident population than used to lure employment." While Carlino and Mills did not study migration directly, their conclusions imply that further inquiry into the impact of local public policies upon household location decisions is warranted.

2. In the spirit of the Tiebout model, numerous researchers have found that local government policy instruments-primarily the property tax-are significant determinants of population levels. 
3. For example, omitting the five variables representing expenditures by category as a percent of total county expenditures had a very minor impact on the magnitude of a small number of the remaining fiscal measures. An anonymous referee suggested alternative specifications that put these variables in per capita or per dollar of county personal income. However, the correlation coefficients among such measures are extremely close to one in many instances, suggesting that multicollinearity might be an even more serious problem using these specifications.

\section{REFERENCES}

Bartik, Timothy J. Who Benefits From State and Local Economic Development Policies? W.E. Upjohn Institute for Employment Research, 1991.

Carlino, Gerald A., and Edwin S. Mills. "Determinants of County Growth." Journal of Regional Science 27 (1987): 39-54.

Fox, William F., Henry W. Herzog, Jr., and Alan M. Schlottmann. "Metropolitan Fiscal Structure and Migration." Journal of Regional Science 29 (1989): 523-536.

Graves, Philip E. "A Reexamination of Migration, Economic Opportunity, and the Quality of Life." Journal of Regional Science 16 (1976): 107-112. . "A Life Cycle Empirical Analysis of Migration and Climate, by Race." Journal of Urban Economics 6 (1979): 135-147. "Migration and Climate." Journal of Regional Science 20 (1980): 227-237.

. "Migration with a Composite Amenity: The Role of Rents." Journal of Regional Science 23 (1983): 541-546.

Graves, Philip E., and Peter Linneman. "Household Migration: Theoretical and Empirical Results." Journal of Urban Economics 6 (1979): 383-404.

Gyourko, Joseph, and Joseph Tracy. "The Importance of Local Fiscal Conditions in Analyzing Labor Markets." Journal of Political Economy 97 (1989): 1208-1231.

Haurin, Donald R., and R. Jean Haurin. "Net Migration, Unemployment, and the Business Cycle." Journal of Regional Science 28 (1988): 239-254.

Hosmer, David W., and Stanley Lemeshow. Applied Logistic Regression. New York: John Wiley and Sons, 1989.

Krumm, Ronald, and Austin Kelly. "Multiperiod Migration Patterns: The Timing and Frequency of Household Responses." Journal of Regional Science 28 (1988): 255-270. 
Linneman, Peter, and Philip E. Graves. "Migration and Job Change: A Multinomial Logit Approach." Journal of Urban Economics 14 (1983): 263-279.

Maddala, G. S. Limited-Dependent and Qualitative Variables in Econometrics. Cambridge and New York: Cambridge University Press, 1983.

Muth, Richard F. "Migration: Chicken or Egg?" Southern Economic Journal 37 (1971): 295-306.

. "Supply-Side Regional Economics." Journal of Urban Economics 29 (1991): 63-69.

Ohio State University. National Longitudinal Survey of Youth. 1984, 1985.

Shaw, R. Paul. "Fiscal Versus Traditional Market Variables in Canadian Migration." Journal of Political Economy 94 (1986): 648-666.

U.S. Bureau of the Census. County and City Data Book. 1983, 1988.

Wasylenko, Michael, and Therese McGuire. "Jobs and Taxes: The Effect of Business Climate on States' Employment Growth Rates." National Tax Journal 38 (1985): 497-511.

Widner, Ralph R., and Gary C. Cornia. "Interstate Tax Competition." Proceedings of the 71st Annual Conference on Taxation: National Tax Institute-Tax Institute of America (1978): 43-53. 